\title{
Determinant Factor of Saving Decision in Syaria Financial Institution
}

\author{
Fitri Nur Hidhayati ${ }^{*}$, Ginanjar Rahmawan ${ }^{2}$ \\ ${ }^{1}$ Management Department, Sekolah Tinggi Ilmu Ekonomi Surakarta \\ ${ }^{2}$ Management Department, Sekolah Tinggi Ilmu Ekonomi Surakarta \\ * Corresponding author \\ Email:fitrimipor@gmail.com
}

\begin{abstract}
.
This research was conducted to determine that the decision to save in Islamic cooperatives is influenced by several factors such as promotion, service quality and products. Variables used in this study are as follows promotion (X1), service quality (X2), product (X3) and decision to save (Y). This research was conducted with a quantitative approach which is one of the methods used to assess a particular population or sample by using a purposive sampling technique using a solvin count so that 88 respondents who are already members of BMT Surya Dana Makmur can be taken. Data collection techniques are by distributing questionnaires online to members using a Likert scale to make it easier for respondents to fill out. The data analysis used is multiple linear regression analysis. Researchers used a tool called SPSS (Statistical Package for Social Science) to see the results of the data obtained. The results of this study promotion have a positive and insignificant effect on the decision to save in Islamic cooperatives. Then the quality of service and products has a positive and significant effect on the decision to save in Islamic cooperatives.
\end{abstract}

Keywords: promotion, service quality, product, saving decision

\section{INTRODUCTION}

The development of the banking world is very rapid, causing competition between cooperatives. Of the cooperatives in the Klaten area, one of them is Baitul Maal wa Tamwil Surya Dana Makmur. This cooperative has a principle that is to prosper members and serve members. With the aim that the members are satisfied with the services provided by the cooperative. With population growth increasing every year, people need to deposit funds in financial institutions such as Islamic banking, consenvional banking and Baitul Maal wa Tamwil Surya Dana Makmur. Along with the increase in customers, it becomes a challenge for Islamic financial institutions to maintain their members.

All cooperatives offer a variety of savings products, which are tailored to customer needs so that they can influence customer decisions, because now many customers are comparing which savings products are the most profitable for them and Baitul Maal wa Tamwil Surya Dana Makmur provides high profit sharing so that customers join in. Second, promote through social media and offline. As well as 
providing for prizes to customers. The third is to establish good relationships with customers, by always being friendly in service so as to gain members' trust to entrust their assets to Baitul Maal wa Tamwil Surya Dana Makmur.

Based on these preliminary thoughts, this research is aimed at analyzing the factors that influence the decision to save in Islamic cooperatives. The framework in this study uses independent variables consisting of promotion, product and service quality, while the dependent variable is the decision to save in Islamic cooperatives.

State that a product is an item that is marketed to consumers in order to gain traction, can be used and used to fulfill wants and needs [7]. Here the product is considered important by consumers and is used to make use of the product according to the needs or desires of the buyer. Research decision to save at Islamic banks in the city of Yogyakarta is positively influenced by the product [14].

Promotion is an activity that is used by companies to get value for members to establish good relationships with members in order to create good value from members as a result of these activities[9]. Promotion is one way of attracting interest and introducing existing savings products in the company by explaining the advantages of these products in order to get a good appraiser to consumers. States that there is a positive and significant effect of the product on customer interest in Baitul Maal wa Tamwil Taruna Sejahtera [12].

Service quality is one of the things that is important to be realized by a company in order to get new members and can minimize the old members from moving to competitors [15]. Service quality can affect members in saving because it is a major factor in fulfilling the expectations of members by means of good and polite service. States that there is a positive and significant impact on service quality on customer interest in Baitul Maal wa Tamwil Taruna Sejahtera [12].

The purchase decision is an activity carried out by members before making a decision to save at the cooperative [8]. Members have a choice of several available alternatives before deciding to use them. Whether to buy or not by looking for information, evaluating and getting the product to meet his wants or needs.

\section{LITERATURE REVIEW}

\section{PROMOTION}

Defined as an action to influence the buyer so that it can introduce the product being marketed to the buyer after which the buyer feels happy in using it [4]. Promotion is one part of the company's marketing mix in informing, reminding and taking the hearts of buyers about the company's products. Promotion is an action to lure buyers to accept products, designs and views [2] 


\section{SERVICE QUALITY}

Service Quality is a standard service procedure that gives value to the services provided to members, both old members and new members, [1]. service quality is the whole of special forms of goods and services that state the ability to meet the needs of members, both directly and indirectly [6]. For companies engaged in the service sector, providing quality services to members is something that must be done in order to achieve company goals.

\section{PRODUCT}

A product is an item that is marketed to the buyer to satisfy the needs of the buyer by getting attractive, owned, used by the buyer [7]. A product is a set of tangible and intangible attributes both in terms of price, packaging, and service from distributors to buyers to fulfill their desires [4]. States that a product that has high quality will get good value compared to competitors' products, so that it can attract the hearts of new members and old members will not move to competitors [11]

\section{SAVING DECISION}

Consumer behavior is an action that is directly involved in obtaining, selecting related products and services in the process of making savings decisions and taking action [10].

There are several factors that influence the decision to save [5], including:

a) Product, is one of the important factors in the decision to save where the product offered must be in accordance with the needs of members.

b) Promotion is an activity to market products to members so that members are interested in using the product.

c) Service is one of the factors that influence saving, because with good service members feel happy.

d) Strategic locations make members want to save.

\section{FRAMEWORK}

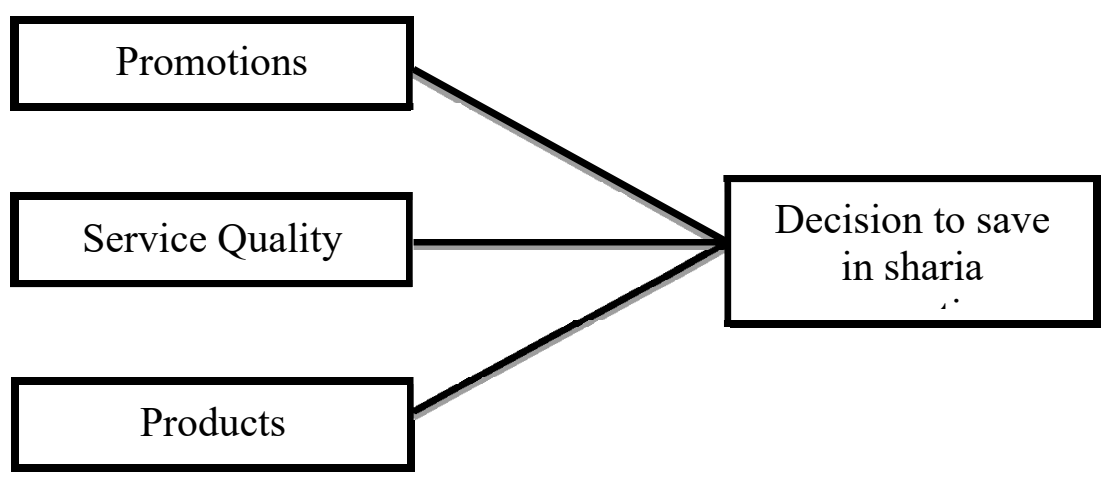

Figure 1 Framework 


\section{METHODS}

The quantitative research method is research that studies problems by looking at careful measurements of the variables used, so as to provide generalizable results, regardless of the time context and situation and the type of data collected, especially survey data [2].

The population in this research is the savings members at BMT Surya Dana Makmur. With the characteristics of being a saver member at BMT Surya Dana Makmur and around 18 to 70 years of age, because 18 years of age is the first requirement to become a member, and already has an identity card. Usually, the average age of the depositors who are elderly is around 70 years. This study required a sample of 88 respondents who used the Slovin formula. Researchers used nonprobality sampling technique with purposive sampling method.

Data collection techniques are by distributing questionnaires online to members using a Likert scale to make it easier for respondents to fill out. In this research using multiple linear regression, to show the influence of independent variables on the dependent variable. The test data used were validity, reliability, multiple linear regression analysis, $t$ test to show the results of the research hypothesis, simultaneous and coefficient of determination.

\section{RESULT AND DISCUSSION}

\section{1) Test the Validity and Reliability of the Instrument}

Table 1. Validity Test Results

\begin{tabular}{lccc}
\hline \multicolumn{1}{c}{ Variable } & r count & r table & Description \\
\hline Promotion 1 & 0,866 & 0,207 & Valid \\
Promotion 2 & 0,818 & 0,207 & Valid \\
Promotion 3 & 0,813 & 0,207 & Valid \\
Qaulity of Service 1 & 0,822 & 0,207 & Valid \\
Qaulity of Service 2 & 0,834 & 0,207 & Valid \\
Qaulity of Service 3 & 0,819 & 0,207 & Valid \\
Qaulity of Service 4 & 0,818 & 0,207 & Valid \\
Product 1 & 0,816 & 0,207 & Valid \\
Product 2 & 0,856 & 0,207 & Valid \\
Product 3 & 0,832 & 0,207 & Valid \\
Product 4 & 0,854 & 0,207 & Valid \\
Decision 1 & 0,785 & 0,207 & Valid \\
Dec ision 2 & 0,857 & 0,207 & Valid \\
Decision 3 & 0,811 & 0,207 & Valid \\
\hline
\end{tabular}

Source: Personal Data, 2021

Table 1 shows the value of $r$ table with the number $\mathrm{N}$ of 88 with a significant level of 0.05 in the distribution of the product moment $r$ table value, so it can be 
determined that the value of the $r$ table is 0.207 . Based on the output value of the validity test, it is known that $r$ count all variables $<r$ table. So it can be concluded that all variables are valid.

Table 2. Reliability Test Results

\begin{tabular}{lcr}
\hline \multicolumn{1}{c}{ Variable } & Value Cronbach's Alpha & Description \\
\hline Promotions & 0,788 & Reliable \\
Service of Quality & 0,841 & Reliable \\
Product & 0,859 & Reliable \\
Saving Decision & 0,748 & Reliable \\
\hline
\end{tabular}

Source: Personal Data, 2021

Table 2 shows that the alpha value for identifying a reliable questionnaire is 0.60 . If the alpha coefficient value is 0.06 , it is stated that the indicators on the questionnaire can be called reliable [3]. And the results of the analysis in table 2 can be said to be reliable.

Table 3. Results of Multiple Linear Regression Test

Coefficients $^{\mathrm{a}}$

\begin{tabular}{|l|r|r|r|r|r|}
\hline \multirow{2}{*}{ Model } & \multicolumn{2}{|c|}{$\begin{array}{c}\text { Unstandardized } \\
\text { Coefficients }\end{array}$} & $\begin{array}{c}\text { Standardized } \\
\text { Coefficients }\end{array}$ & \multirow{2}{*}{ T } & \multirow{2}{*}{ Sig. } \\
\cline { 2 - 4 } & \multicolumn{1}{|c|}{ B } & \multicolumn{1}{|c|}{$\begin{array}{c}\text { Std. } \\
\text { Error }\end{array}$} & \multicolumn{1}{|c|}{ Beta } & & \\
\hline (Constant) & 2,205 &, 734 & & 3,002 &, 004 \\
Promotion &, 080 &, 104 &, 087 &, 764 &, 447 \\
Sevice Quality &, 193 &, 093 &, 262 & 2,084 &, 040 \\
Product &, 347 &, 097 &, 464 & 3,568 &, 001 \\
\hline
\end{tabular}

a. Dependent Variable: Saving Decision

Based on the SPSS output above, the regression line equation is obtained:

$$
\mathrm{Y}=2.205+0.080 \mathrm{X} 1+0.193 \mathrm{X} 2+0.347 \mathrm{X} 3+\mathrm{e}
$$

The description of the regression line equation above includes:

a) The constant is 2.205 which means the independent variable: Promotion (X1), Service Quality (X2) Product (X3) so that the decision to save in Islamic cooperatives increases by 2.205

b) The promotion coefficient value of 0.080 means that every 1 score increase for promotion will be followed by an increase in saving decisions by 0.080

c) The value of the service quality coefficient of 0.193 means that every 1 increase in service quality will be followed by an increase in saving decisions by 0.193 . 
d) The product coefficient value is 0.347 , meaning that every increase of 1 suspension for the product will be followed by an increase in the decision to save by 0.347

Table 4. T Test Results

Coefficients $^{a}$

\begin{tabular}{|l|r|r|r|r|r|}
\hline \multirow{2}{*}{ Model } & \multicolumn{2}{|c|}{$\begin{array}{c}\text { Unstandardized } \\
\text { Coefficients }\end{array}$} & $\begin{array}{c}\text { Standardized } \\
\text { Coefficients }\end{array}$ & \multirow{2}{*}{ T } & \multirow{2}{*}{ Sig. } \\
\cline { 2 - 4 } & \multicolumn{1}{|c|}{ B } & \multicolumn{1}{c|}{$\begin{array}{c}\text { Std. } \\
\text { Error }\end{array}$} & \multicolumn{1}{|c|}{ Beta } & & \\
\hline 1 (Constant) & 2,205 &, 734 & & 3,002 &, 004 \\
Promotion &, 080 &, 104 &, 087 &, 764 &, 447 \\
Service Quality &, 193 &, 093 &, 262 & 2,084 &, 040 \\
Product &, 347 &, 097 &, 464 & 3,568 &, 001 \\
\hline
\end{tabular}

a. Dependent Variable: Saving Decision

Source: Personal Data (2021)

Based on the $t$ test above shows that:

a) The promotion variable produces $t$ count of 0.764 while the significance value is $0.447>0.05$, so the hypothesis is rejected, meaning that it does not have a positive effect on the decision to save.

b) The service quality variable produces $t$ count of 2.084 while the significance level is $0.040<0.05$, so the hypothesis is accepted, meaning that there is an effect of service quality on the decision to save.

c) The product variable produces a t count of 3.568 while the significance level is $0.001<0.05$, so the hypothesis is accepted, meaning that there is an effect of the product on the decision to save.

Table 5. F Test Results ANOVAa

\begin{tabular}{|c|c|c|c|c|c|}
\hline Model & $\begin{array}{l}\text { Sum of } \\
\text { Squares }\end{array}$ & Df & $\begin{array}{l}\text { Mean } \\
\text { Square }\end{array}$ & $\mathrm{F}$ & Sig. \\
\hline 1 Regressior & 66,548 & 3 & 22,183 & 38,539 &, $000^{b}$ \\
\hline Residual & 48,350 & 84 & ,576 & & \\
\hline Total & 114,898 & 87 & & & \\
\hline
\end{tabular}

a. Dependent Variable: Saving decision

b. Predictors: (Constant), Promotions, Sevice Qaulity, Products

Source: Personal Data (2021)

It can be seen from the results of the $f$ test above that the level of significance is $0.000<0.05$, which states that promotion, service quality, product stimuli affect the decision to save. 
Table 6. Coefficient of Determination

Model Summary

\begin{tabular}{|l|l|l|l|l|}
\hline Model & $\mathrm{R}$ & $\begin{array}{c}\mathrm{R} \\
\text { Square }\end{array}$ & $\begin{array}{c}\text { Adjusted } \\
\mathrm{R} \\
\text { Square }\end{array}$ & $\begin{array}{c}\text { Std. } \\
\text { Error of } \\
\text { the } \\
\text { Estimate }\end{array}$ \\
\hline 1 &, $761^{\mathrm{a}}$ &, 579 &, 564 &, 75868 \\
\hline
\end{tabular}

a. Predictors: (Constant), Products, Promotions, Service

Quality

b. Dependent Variable: Saving Decision

Source: Personal Data (2021)

The calculation of table 6 states that the value of Adjusted R Square $=0.564$ which indicates the influence of the free variable of $56.4 \%$, and the rest is influenced by other factors such as trust and location.

\section{CONCLUSION}

Based on the description of the research results, conclusions can be drawn including:

a) The promotion variable has no significant and positive effect on the saving decision variable, so the first hypothesis is rejected.

b) The service quality variable has a significant and positive influence on the decision to save, so the second hypothesis is accepted.

c) The product variable has a significant and positive influence on the decision to save, so the third hypothesis is accepted.

d) The decision to save is influenced jointly or simultaneously by promotion, service quality and product.

Suggestions that can be echoed by researchers include:

a) The management team of sharia cooperatives must maintain the existing dependent variable, because of the good assessment of the savings members at Baitul Maal wa Tamwil Surya Dana Makmur. It can be increased on the promotion variable so that it can have a significant effect on saving decisions, by distributing brochures, communicating directly with prospective new members.

b) For saving members at BMT Surya Dana Makmur, please give their opinions or suggestions so that they can help the cooperative to make new savings products so that they can improve their savings decisions.

c) For future researchers, hopefully we can develop other variables outside of promotion, service quality and product variables, so that they can produce even more accurate output. 


\section{ACKNOWLEDGMENTS}

The authors are grateful to my promotion and all staff ini Sekolah Tinggi Ilmu Ekonomi Surakarta for always give me support to finish my article. Also thanks for all my friend and family for supporting me in my study.

\section{REFERENCES}

[1] A.A. Anwar Prabu Mangkunegara. 2002. Manajemen Sumber Daya Manusia. Perusahaan. Bandung: PT. Remaja Rosdakarya.

[2] Bintarti, Surya., 2015, Metodologi Penelitian Ekonomi Manajemen, Mitra Wacana Media, Jakarta.

[3] Priyatno, Dwi., 2016, Belajar Alat Analisis Data dan Cara Pengolahannya dengan SPSS, Gava Media, Yogyakarta.

[4] Buchari Alma, (2007), Manajamen Pemasaran dan Pemasaran Jasa, Alfabeta, Bandung.

[5] Sumantri, Bagja. 2014. "Pengaruh Kualitas Pelayanan dan Produk Pembiayaan terhadap Minat dan Keputusan menjadi Nasabah di Bank Syariah". Jurnal Economia, Volume 10. Nomor 2. Hal.. 34-48 Mewujudkan Layanan Prima. Yogyakarta Andi Offset..

[6] Kotler, Philip (2000). Prinsip - Prinsip Pemasaran Manajemen, Jakarta : Prenhalindo.

[7] Kotler dan Amstrong.2001. Prinsip Prinsip Pemasaran. Jakarta. Erlangga.

[8] Kotler, Philip dan Keller. 2007. Manajemen Pemasaran. Edisi 12. Jilid I. PT Indeks Jakarta. .

[9] Kotler,Philip dan Gary Amstrong. 2012. Prinsip Prinsip Pemasaran. Edisi 13.Jilid I. Jakarta. Erlangga

[10] Tjiptono, Fandy. (2002). Strategi Pemasaran. Yogyakarta : Penerbit Andi..

[11] Kasmir.2010. Pemasaran Bank. Kencana. Jakarta.

[12] Maulida, Isnaine. 2016. “Aanlisis Pengaruh Promosi dan Pelayanan terhadap Minat Nasabah Menabung pada BMT Taruna Sejahtera Cabang Tuntang”. Skripsi. Institut Agama Islam Negeri (IAIN) syekh Nurjati Cirebon. Cirebon

[13] Tjiptono, Fandy. 2008. Service Management

[14] Tjiptono, Fandy dan Gregorius Chandra. 2012. Service Quality dan Satisfaction. Yogyakarta. Andi Offset 